\title{
Genetic parameters of traits at the juvenile stage of different assai palm tree progenies
}

\author{
Patricia Cardoso Andrade Navegantes ${ }^{(1)}$, Maria do Socorro Padilha de Oliveira(2) \\ and José Airton Rodrigues Nunes ${ }^{(1)}$
}

\begin{abstract}
(1)Universidade Federal de Lavras, Avenida Doutor Sylvio Menicucci, no 1.001, Caixa Postal 3037, CEP 37200-000 Lavras, MG, Brazil. E-mail: engpatricia26@gmail.com, jarnunes@dbi.ufla.br ${ }^{(2)}$ Embrapa Amazônia Oriental, Travessa Dr. Enéas Pinheiro, s/no, Marco, Caixa Postal 48, CEP 66095-903 Belém, PA, Brazil. E-mail: socorro-padilha.oliveira@embrapa.br
\end{abstract}

\begin{abstract}
The objective of this work was to estimate genetic parameters of traits at the juvenile stage of different assai palm (Euterpe oleracea) tree progenies, as well as to select among and within the most promising for fruit production. A total of 34 half-sib and 16 full-sib progenies were evaluated in a completely randomized design with eight replicates and one plant per plot. Nine traits were measured in five harvests, and the data were analyzed using the mixed model approach. The genetic variance was significant for most of the traits. Progeny-mean heritabilities showed moderate magnitudes, ranging from $51 \%$ for number of dead leaves to $59 \%$ for leaf sheath length. In general, the genetic correlations were positive and had magnitudes varying from moderate to very high. The genetic gains were more expressive for the traits plant height, leaf sheath length, and girth circumference. The full-sib progenies P33, P37, and P42 are promising for fruit production.

Index terms: Euterpe oleracea, full-sib, genetic correlation, half-sib, heritability, mixed models, selection gain.

\section{Parâmetros genéticos de características na fase juvenil de diferentes progênies de açaizeiro}

Resumo - O objetivo deste trabalho foi estimar parâmetros genéticos de características no estágio juvenil de diferentes progênies de açaí (Euterpe oleracea), bem como proceder à seleção entre e dentro daquelas mais promissoras para produção de frutos. Foram avaliadas 34 progênies de meios-irmãos e 16 progênies de irmãos germanosnodelineamentointeiramentecasualizado, comoitorepetiçõese parceladeumaplanta. Novecaracteres foram mensurados em cinco colheitas, e os dados foram avaliados por meio da abordagem de modelos mistos. A variância genética foi significativa para a maioria dos caracteres. As herdabilidades na média de progênies exibiram magnitudes moderadas, com variação de $51 \%$ para número de folhas mortas a $59 \%$ para comprimento da bainha foliar. Em geral, as correlações genéticas entre os caracteres foram positivas e com magnitudes de moderada a muito alta. Os ganhos genéticos foram mais expressivos para os caracteres altura de planta, comprimento da bainha foliar e comprimento do coleto. As progênies de irmãos germanos P33, P37 e P42 mostraram-se promissoras para produção de frutos.
\end{abstract}

Termos para indexação: Euterpe oleracea, irmãos germanos, correlação genética, meio-irmãos, herdabilidade, modelos mistos, ganho com seleção.

\section{Introduction}

Assai palm (Euterpe oleracea Mart.) is a species found in the Amazon region, with dual economic use as a source of fruit and palm heart. Fruit production is still strongly based on extraction from dense and diverse natural populations in floodplain areas, and the state of Pará, Brazil, is the largest producer and main consumer (Yokomizo et al., 2016). Currently, the consumption of assai has expanded to all Brazilian states and to other countries, which is mainly attributed to the flavor and high nutritive value of the assai fruit (Yamaguchi et al., 2015).

For commercial crops of assai palm, it is necessary to use improved seeds. With this aim, from the 1980s onwards, Embrapa Amazônia Oriental started an assai breeding program focused on fruit production. In 2004, the open-pollinated BRS Pará cultivar, originated from progenies of natural populations, was released (Oliveira \& Farias Neto, 2004). This aided in the development and consequent productivity of the assai crops (Rufino et al., 2011). 
The optimization of the assai fruit proactive chain, however, depends on the continuous development of new cultivars of high value of cultivation and use. For this reason, the assai breeding program has adopted new breeding methods, including the artificial hybridization of superior plants with target traits, for the subsequent generation of half- and full-sib progenies (Oliveira et al., 2009). Half-sib progeny tests have been one of the most explored strategies, allowing to estimate genetic parameters and, consequently, to provide a better understanding about the available genetic variance, subsidizing selection strategies to maximize genetic gains (Farias Neto et al., 2012). However, recently, the identification of more promising plants has focused on obtaining and evaluating full-sib progenies from biparental crosses.

The ideotype of an assai palm cultivar should present desirable phenotypes for multiple traits, such as high fruit production, early fruiting, fruits with high anthocyanin content, stability in the production of bunches throughout the year, and resistance or tolerance to the main biotic or abiotic factors (Oliveira et al., 2009). Considering the species is perennial and starts producing in the third year of planting, it is important to carry out the initial screening of plants at earlier stages. A possibility is assessing, at the juvenile stage, the genetic variation of traits like number of leaves, plant height, and number of tillers. Some studies have shown the existence of correlations between traits at the juvenile and productive stages, which may be used for early selection aiming to obtain indirect genetic gain for assai production (Farias Neto et al., 2012). This way, early selection might allow discarding non-promising plants and reducing costs associated with subsequent phases of evaluation.

The objective of this work was to estimate genetic parameters of traits at the juvenile stage of different assai palm tree progenies, as well as to select among and within the most promising for fruit production.

\section{Materials and Methods}

A total of 52 genotypes were evaluated: 34 half-sib progenies (HSP) of E. oleracea; 16 full-sib progenies (FSP) of E. oleracea; and two checks consisting of an open-pollinated progeny of Euterpe precatoria Mart. and of the BRS Pará (E. oleracea) cultivar. The HSP consisted of 27 progenies from the municipality of
Santa Izabel do Pará, in the state of Pará, Brazil; 4 progenies from the active germplasm bank of Embrapa Amazônia Oriental; and 3 open-pollinated progenies. The experimental design was completely randomized, with eight replicates and one plant per plot, with a spacing of $5 \mathrm{~m}$ between rows and $5 \mathrm{~m}$ between plants.

The experiment was conducted in an experimental area of Embrapa Amazônia Oriental, located in the metropolitan region of Belém, also in the state of Pará, Brazil (01 $277^{\prime} 40^{\prime \prime} \mathrm{S}, 48^{\circ} 26^{\prime} 59^{\prime \prime} \mathrm{W}$, at $200 \mathrm{~m}$ altitude). The soil of the area is classified as a medium-textured Latossolo Amarelo (Santos et al., 2013), i.e, Xanthic Hapludox. The climate is predominantly hot and humid equatorial $\left(\mathrm{Af}_{\mathrm{i}}\right)$ according to Köppen's classification, with an average temperature of $28^{\circ} \mathrm{C}$, relative humidity of $80 \%$, and rainfall above $3,000 \mathrm{~mm}$.

Planting was carried out in February 2011. Seedlings were placed in pits of $40 \times 40 \times 40 \mathrm{~cm}$, were fertilized, and subjected to the crop management practices recommended for assai palm tree in the region (Oliveira et al., 2000).

Plants were evaluated semiannually in the period from October 2011 to October 2013, totaling five measurements throughout the juvenile stage. The following traits were determined: total number of leaves (NL), number of emerged leaves (NEL), number of dead leaves (NDL), total leaf length (TLL, cm), leaf sheath length (LSL, cm), plant height $(\mathrm{PH}, \mathrm{cm})$, girth circumference $(\mathrm{GC}, \mathrm{cm})$, number of leaflet pairs (NLP), and number of tillers (NT).

Data were analyzed by the mixed model approach. Individual analyses per measurement were performed according to the following statistical model:

$$
\mathrm{y}=\mathrm{Xr}+\mathrm{Z}_{1} \mathrm{~g}+\mathrm{Z}_{2} \mathrm{~g} \text { ' }+\mathrm{e}
$$

where $y$ is the data vector; $r$ is the vector of the fixed effects of the types of genetic treatment, i.e., HSP, FSP and check, added to the overall mean; $g$ is the vector of the additive effects of HSP, with $\mathrm{g} \sim \mathrm{MNV}\left(0, \mathrm{I}_{\mathrm{g}}{ }^{2}\right)$, where $\mathrm{MNV}$ is the multivariate normal distribution and $\sigma_{\mathrm{g}}{ }^{2}$ is the variance among HSP; $\mathrm{g}^{\prime}$ is the vector of the genotypic effects of FSP, with g' $\operatorname{MNV}\left(0, \mathrm{I}_{\mathrm{g}}{ }^{2}\right)$, where $\sigma_{\mathrm{g}}{ }^{2}$ is the variance among FSP; $\mathrm{e}$ is the vector of errors, with $\mathrm{e} \sim \operatorname{MNV}\left(0, \mathrm{I}_{\mathrm{e}}{ }^{2}\right)$, where $\sigma_{\mathrm{e}}{ }^{2}$ is the residual variance; and $X, Z_{1}$, and $Z_{2}$ are the incidence matrices for the $r$, g, and g' effects, respectively.

Subsequently, the joint analysis was performed using the five obtained measurements, according to the following statistical model: 


$$
\mathrm{y}=\mathrm{Xm}+\mathrm{Z}_{1} \mathrm{~g}+\mathrm{Z}_{2} \mathrm{~g}^{\prime}+\mathrm{Z}_{3} \mathrm{p}+\mathrm{Z}_{4} \mathrm{u}+\mathrm{Z}_{5} \mathrm{v}+\mathrm{e}^{\prime}
$$

where $m$ is the vector of the fixed effects of the combinations between measurement and type of genetic treatment, added to the overall mean; $p$ is the vector of the random effects of the plots, with $\mathrm{p} \sim \mathrm{MNV}$ $\left(0, I \sigma_{p}{ }^{2}\right)$, where $\sigma_{p}^{2}$ is the variance among plots; $u$ is the vector of the random effects of the HSP $\mathrm{x}$ measurement interaction, with $\mathrm{u} \sim \operatorname{MNV}\left(0, \mathrm{I}_{\mathrm{u}}{ }^{2}\right)$, where $\sigma_{\mathrm{u}}{ }^{2}$ is the variance of the HSP $\mathrm{x}$ measurement interaction; $\mathrm{v}$ is the vector of the random effects of the FSP $\mathrm{x}$ measurement interaction, with $\mathrm{v} \sim \operatorname{MNV}\left(0, \mathrm{I}_{\mathrm{v}}{ }^{2}\right)$, where $\sigma_{\mathrm{v}}{ }^{2}$ is the variance of the FSP $x$ measurement interaction; $e^{\prime}$ is the vector of errors, with e' $\sim \operatorname{MNV}\left(0, \mathrm{I}_{\mathrm{e}^{\mathrm{e}}}{ }^{2}\right)$, where $\sigma_{\mathrm{e}}{ }^{2}$ is the residual variance; and $\mathrm{X}, \mathrm{Z}_{1}, Z_{2}, Z_{3}, Z_{4}$, and $\mathrm{Z}_{5}$ are the incidence matrices for $\mathrm{m}, \mathrm{g}, \mathrm{g}, \mathrm{p}, \mathrm{u}$, and $\mathrm{v}$, respectively.

For the prediction of the individual additive genetic values and assuming the absence of dominance, the following statistical model was fitted:

$$
\mathrm{y}+\mathrm{Xm}+\mathrm{Z}_{6} \mathrm{a}+\mathrm{Z}_{7} \mathrm{a}^{\prime}+\mathrm{Z}_{3} \mathrm{p}+\mathrm{Z}_{4} \mathrm{u}+\mathrm{Z}_{5} \mathrm{v}+\varepsilon
$$

where $a$ is the vector of the individual additive effects of HSP, with $\mathrm{a} \sim \operatorname{MNV}\left(0, A \sigma_{\mathrm{a}}^{2}\right)$, where $\mathrm{A}$ is the matrix that contains the additive genetic relationships and $\sigma_{\mathrm{a}}{ }^{2}$ is the additive variance; $\mathrm{a}$ ' is the vector of the individual additive effects of FSP, with a' $\sim \operatorname{MNV}(0$, $\mathrm{A}^{\prime} \sigma_{\mathrm{a}^{2}}{ }^{2}$ ), where $\mathrm{A}^{\prime}$ is the matrix that contains the additive genetic relationships and $\sigma_{\mathrm{a}}{ }^{2}$ is the additive variance; $\varepsilon$ is the vector of errors, with $\varepsilon \sim \operatorname{MNV}\left(0, I^{2}\right)$, where $\sigma^{2}$ is the residual variance; and $\mathrm{X}, \mathrm{Z}_{6}, \mathrm{Z}_{7}, \mathrm{Z}_{3}, \mathrm{Z}_{4}$, and $Z_{5}$ are the incidence matrices for $\mathrm{m}, \mathrm{a}, \mathrm{a}, \mathrm{p}, \mathrm{u}$, and $\mathrm{v}$, respectively.

The variance components were estimated by the residual maximum likelihood (REML) method, and significance was evaluated by the likelihood ratio test, at $5 \%$ probability. The $95 \%$ confidence intervals of the predictions were determined based on the best linear unbiased predictor (Blup) of the random effects, and the corresponding caterpillar plots were generated. The best linear unbiased estimator (Blue) was also used to obtain estimates of fixed effects and their standard errors. The analyses of the first and second models were performed with the SAS system for Windows, version 9.3 (SAS Institute Inc., Cary, NC, USA), while the third model was analyzed using the Selegen software (Resende, 2016).

The accuracy associated with the predicted genetic values of E. oleracea progenies was estimated by the following expression (Mrode, 2005; Resende, 2007):

$$
r_{\tilde{g} g}=\sqrt{1-\frac{\bar{P} \bar{E} \bar{V}}{\bar{\sigma}_{g}^{2}}}
$$

where PEV is the prediction error variance. The individual heritability $\left(\mathrm{h}_{\mathrm{i}}^{2}\right)$ and the progeny-mean heritability $\left(\mathrm{h}^{2}\right)$ were also estimated, as well as the average genetic correlations among progenies across the measurements $\left(\mathrm{r}_{\mathrm{gm}}\right)$. The gain with selection for each trait was also determined based on the predicted genetic values of the individuals of half- and full-sib progenies, admitting selection intensities of 10 and $20 \%$.

Pearson correlations were run between traits, and the interrelationship among progenies and traits was analyzed with the GGE biplot method (Yan \& Rajcan, 2002). For this, the predictions of the progeny genetic values obtained with the GGEbiplotGUI package were used (Frutos et al., 2014).

The gain with multi-trait selection over the five measurements was calculated by the method of independent culling levels. Four traits (NL, TLL, LSL, and GC) were considered, with the minimum selection level above the Blup mean of the individuals. Subsequently, the top ten individuals for all evaluated traits were classified and identified by the graphic representation proposed by Nunes et al. (2005).

\section{Results and Discussion}

For the nine juvenile traits assessed, the accuracy for progeny selection ranged from 13 to $83 \%$ (Table 1). Considering only HSP, the accuracy was moderate for NDL (62\%) and NT (50\%), while for FSP, almost all traits showed moderate to high accuracy, except NT $(42 \%)$. Therefore, in general, a moderate and high reliability was observed for the prediction of the true genotypic values of the traits of the progenies evaluated based on the experimental data (Resende \& Duarte, 2007).

Genetic variances among FSP were statistically nonnull for almost all traits, except for NT. The $\mathrm{h}^{2}$ estimates for FSP allowed genetic gain, and the obtained values ranged from $17.76 \%$ for NT to $68.82 \%$ for LSL; the traits LSL, NL, and PH showed to be more promising for progeny selection (Table 1). Among HSP, however, the genetic variances were not significant for all traits. These results indicate a low chance to achieve success with selection for HSP. When testing HSP, Farias 
Neto et al. (2005) also did not detect any significant differences for plant height and number of green leaves, but observed genetic variation for stipe diameter at breast height and number of tillers at the juvenile stage. While evaluating open-pollinated progenies, Farias Neto et al. (2012), however, found non-null heritabilities for plant height, number of green leaves and number of tillers, confirming the possibility of genetic gains with selection for these traits. In another study with assai palm accessions at the reproductive stage, genetic divergence was reported for stipe height, number of leaves, and leaf sheath length (Oliveira et al., 2007).

The mixed model approach allows to select promising progenies from the Blup predictions of the breeding value and from their prediction intervals, synthesized by the caterpillar plots (Figure 1). It is possible to identify progenies with values superior or inferior to the mean and that will represent the selection gains in the desired direction. Progeny 37 stood out for NEL (Figure $1 \mathrm{~A}$ ), progeny 33 for LSL (Figure $1 \mathrm{~B}$ ), and progenies 28, 30, and 35 for $\mathrm{PH}$ due to their lowest values (Figure $1 \mathrm{C}$ ).

In perennial plants, it is common for the same traits to be measured in the same plant at different stages, such as the juvenile one, and it is important to analyze the interaction between progenies and measurements. In the present study, the variance of the progeny $\mathrm{x}$ measurement interaction was significant $(p \leq 0.05)$ for LSL, PH, GC, and NLP, but only for FSP (Table 1). Moreover, the estimates of the genetic correlation obtained through the measurements $\left(\mathrm{r}_{\mathrm{gmFS}}\right)$ were high $(>77 \%)$, suggesting the predominance of a simple interaction for these traits. Yokomizo et al. (2010) evaluated several agronomic and reproductive traits, including plant height, circumference of the older stipe

Table 1. Estimates of genetic variance among half-sib (HSP) $\left(\sigma_{\mathrm{g}}{ }^{2}\right)$ and full-sib (FSP) $\left(\sigma_{\mathrm{g}^{2}}{ }^{2}\right)$ progenies of assai palm (Euterpe oleracea); variance of the HSP x measurements $\left(\sigma_{\mathrm{u}}{ }^{2}\right)$ and FSP $\mathrm{x}$ measurements $\left(\sigma_{\mathrm{v}}{ }^{2}\right)$ interactions; heritabilities in the means of progenies $\left(\mathrm{h}_{\mathrm{g}}{ }_{\mathrm{g}}\right.$ and $\left.\mathrm{h}^{2}{ }_{\mathrm{g}}\right)$; estimates of genetic correlations among progenies across the measurements $\left(\mathrm{r}_{\mathrm{gmHS}}\right.$ and $\mathrm{r}_{\mathrm{gmFS}}$ ); phenotypic means of HSP $\left(\overline{\mathrm{y}}_{\mathrm{HS}}\right)$, of FSP $\left(\overline{\mathrm{y}}_{\mathrm{FS}}\right)$, of the BRS Pará cultivar ( $\overline{\mathrm{y}}_{\mathrm{BRS} \text { Pará}}$ ), of the open-pollination progeny of Euterpe precatoria $\left(\overline{\mathrm{y}}_{51}\right)$; and accuracy in the mean of $\mathrm{HSP}\left(\mathrm{r}_{\mathrm{g} g \mathrm{gS}}\right)$ and of FSP $\left(\mathrm{r}_{\mathrm{g}_{\mathrm{g}} \mathrm{g}_{\mathrm{g}} \mathrm{FS}}\right)$ for nine juvenile traits evaluated in five measurements ${ }^{(1)}$.

\begin{tabular}{|c|c|c|c|c|c|c|c|c|c|}
\hline Parameter & NL & NEL & NDL & TLL & LSL & $\mathrm{PH}$ & $\mathrm{GC}$ & NLP & NT \\
\hline$\sigma_{\mathrm{g}}^{2}$ & 0.0296 & 0.0000 & 0.0510 & 0.0000 & 5.5024 & 5.8807 & 0.0615 & 1.2328 & 0.0619 \\
\hline$\sigma_{\mathrm{g}^{2}}{ }^{2}$ & $0.5315^{*}$ & $0.1744^{*}$ & $0.0671^{*}$ & $91.7788^{*}$ & $57.1202 *$ & $95.6260 *$ & $5.6347^{*}$ & $5.9214^{*}$ & 0.0443 \\
\hline$\sigma_{u}^{2}$ & 0.0000 & 0.0240 & 0.0083 & 0.0000 & 0.0000 & 0.0000 & 0.2997 & 0.0000 & 0.0435 \\
\hline$\sigma_{v}^{2}$ & 0.0000 & 0.0233 & 0.0000 & 0.0000 & $12.1230^{*}$ & $31.3509^{*}$ & $1.1315^{*}$ & $1.0328 *$ & 0.0000 \\
\hline $\mathrm{h}_{\mathrm{g}}^{2}$ & 0.0350 & 0.0160 & 0.3851 & 0.0289 & 0.0576 & 0.0275 & 0.0205 & 0.0655 & 0.2516 \\
\hline $\mathrm{h}_{\mathrm{g}^{\prime}}^{2}$ & 0.6437 & 0.6112 & 0.5072 & 0.5581 & 0.6882 & 0.6341 & 0.6056 & 0.5516 & 0.1776 \\
\hline $\mathrm{r}_{\mathrm{gmHS}}$ & 0.4763 & 0.0988 & 0.7501 & 0.7142 & 0.4421 & 0.3514 & 0.6101 & 0.3114 & 0.8233 \\
\hline$r_{\mathrm{gmFS}}$ & 0.9852 & 0.9323 & 0.9015 & 0.9784 & 0.8196 & 0.7926 & 0.8734 & 0.7756 & 0.9155 \\
\hline$\overline{\mathrm{y}}_{\mathrm{HS}}$ & 6.05 & 3.23 & $2.19^{\#}$ & 96.99 & $35.37^{\#}$ & 46.51 & 14.52 & 26.52 & 1.43 \\
\hline$\overline{\mathrm{y}}_{\mathrm{FS}}$ & 6.30 & 3.30 & $2.34^{\#}$ & $107.67^{\#}$ & $43.63^{\#}$ & $56.37^{\#}$ & $16.00^{\#}$ & $28.32^{\#}$ & 1.65 \\
\hline $\bar{y}_{\text {BRS Pará }}$ & 5.04 & 2.72 & 1.44 & 79.80 & 23.44 & 31.96 & 10.76 & 22.36 & 0.96 \\
\hline$\overline{\mathrm{y}}_{51}$ & 6.20 & 3.46 & 1.99 & 104.51 & 33.45 & 42.79 & 15.52 & 28.89 & 1.40 \\
\hline $\mathrm{r}_{\mathrm{gg} \mathrm{HS}}$ & 0.19 & 0.13 & 0.62 & 0.17 & 0.24 & 0.17 & 0.14 & 0.26 & 0.50 \\
\hline$r_{\tilde{g} \mathrm{~g}^{\prime} \mathrm{gS}}$ & 0.80 & 0.78 & 0.71 & 0.75 & 0.83 & 0.80 & 0.78 & 0.74 & 0.42 \\
\hline
\end{tabular}

(1)NL, number of leaves (unit); NEL, number of emerged leaves (unit); NDL, number of dead leaves (unit); TLL, total leaf length (cm); LSL, leaf sheath length (cm); PH, plant height (cm); GC, girth circumference (cm); NLP, number of leaflet pairs (unit); and NT, number of tillers (unit). *Significant by the likelihood ratio test (LRT), $\chi_{(0.05 ; 1)}^{2}=3.84$. ${ }^{\#}$ Significant contrast between the progenies studied and the BRS Pará cultivar. 

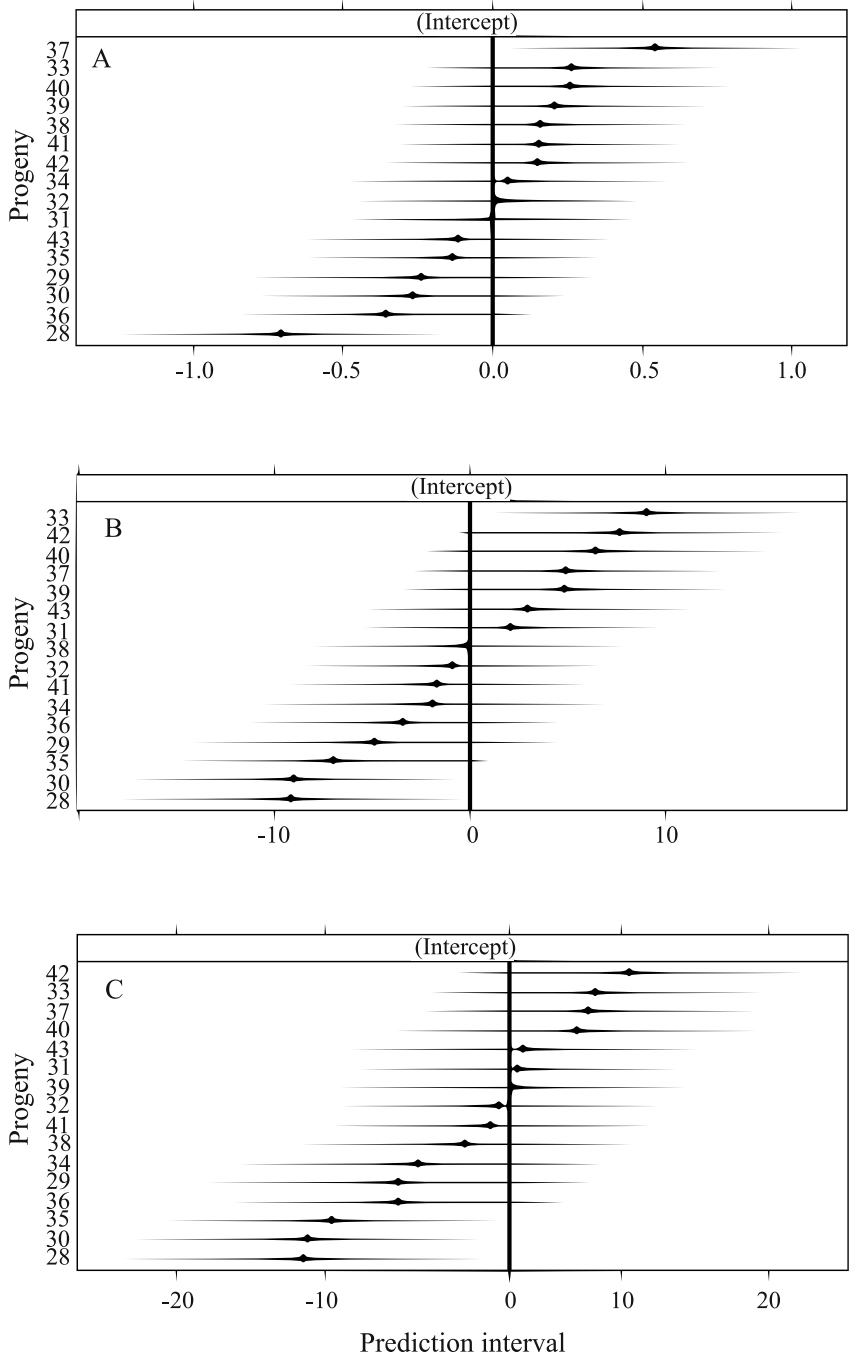

Figure 1. Prediction interval of the genetic values for fullsib progenies of assai palm (Euterpe oleracea) obtained based on the traits: A, number of emerged leaves (NEL); B, leaf sheath length (LSL); and C, plant height (PH). and number of leaves in assai palm, and also verified the effect of this interaction on progenies of different populations.

Overall, the measured traits were positively correlated (Table 2). The traits NL, TLL, LSL, PH, GC, and NLP were highly correlated, whereas NEL had a moderate association with NDL. The genetic correlations in FSP over the measurements were high, showing that the progenies tend to repeat their initial performance at later stages. This was also reported by Farias Neto et al. (2012) for plant height at the juvenile stage and by Oliveira et al. (2000) for number of green leaves, leaf sheath length, and stipe height, but with lower magnitudes, at the adult stage.

Assuming the selection of 10 and $20 \%$ of the plants, it was observed that, in general, the best individuals were those from the top FSP, i.e., progenies 33, 34, 37, and 42 (Figure $2 \mathrm{~A}$ to $\mathrm{H}$ ). Some progenies presented favorable phenotypes for several traits, such as progenies 37 and 42, which are promising for the assai palm breeding program. The expected genetic gains were expressive, especially for the traits LSL, PH, and GC (Figure 3). It should be noted that there was an imbalance in the dataset, mainly related to the number of individuals per progeny. In this case, the use of the mixed model approach is more appropriate, because it allows a more accurate estimate of the genetic gains from the Blup predictions of the genetic values (Resende \& Dias, 2000; Piepho \& Eckl, 2013).

In average, FSP showed better performance than the check 'BRS Pará' for almost all the assessed traits at the juvenile stage (Figure 4). In addition, the progenies 42 and 33 exhibited the best performances for the

Table 2. Estimates of genetic correlations between juvenile traits obtained from the evaluation of full-sib progenies of assai palm (Euterpe oleracea) in five measurements ${ }^{(1)}$.

\begin{tabular}{lccccccc}
\hline Trait & NEL & NDL & TLL & LSL & PH & GC & NLP \\
\hline NL & $0.92^{*}$ & 0.77 & $0.89^{*}$ & $0.86^{*}$ & $0.91^{*}$ & $0.94^{*}$ & $0.95^{*}$ \\
NEL & 1 & 0.60 & 0.75 & 0.79 & 0.81 & $0.86^{*}$ & $0.86^{*}$ \\
NDL & & 1 & 0.65 & 0.73 & 0.71 & 0.69 & $0.94^{*}$ \\
TLL & & 1 & $0.88^{*}$ & $0.94^{*}$ & $0.90^{*}$ \\
LSL & & & 1 & $0.97^{*}$ & $0.92^{*}$ & $0.85^{*}$ \\
PH & & & & 1 & & $0.97^{*}$ & $0.90^{*}$ \\
GC & & & & & & 1 \\
NLP & & & & & & $0.94^{*}$ \\
\hline
\end{tabular}

(1)NL, number of leaves (unit); NEL, number of emerged leaves (unit); NDL, number of dead leaves (unit); TLL, total leaf length (cm); LSL, leaf sheath length (cm); PH, plant height (cm); GC, girth circumference (cm); and NLP, number of leaflet pairs (unit). *Significant by the likelihood ratio test. 

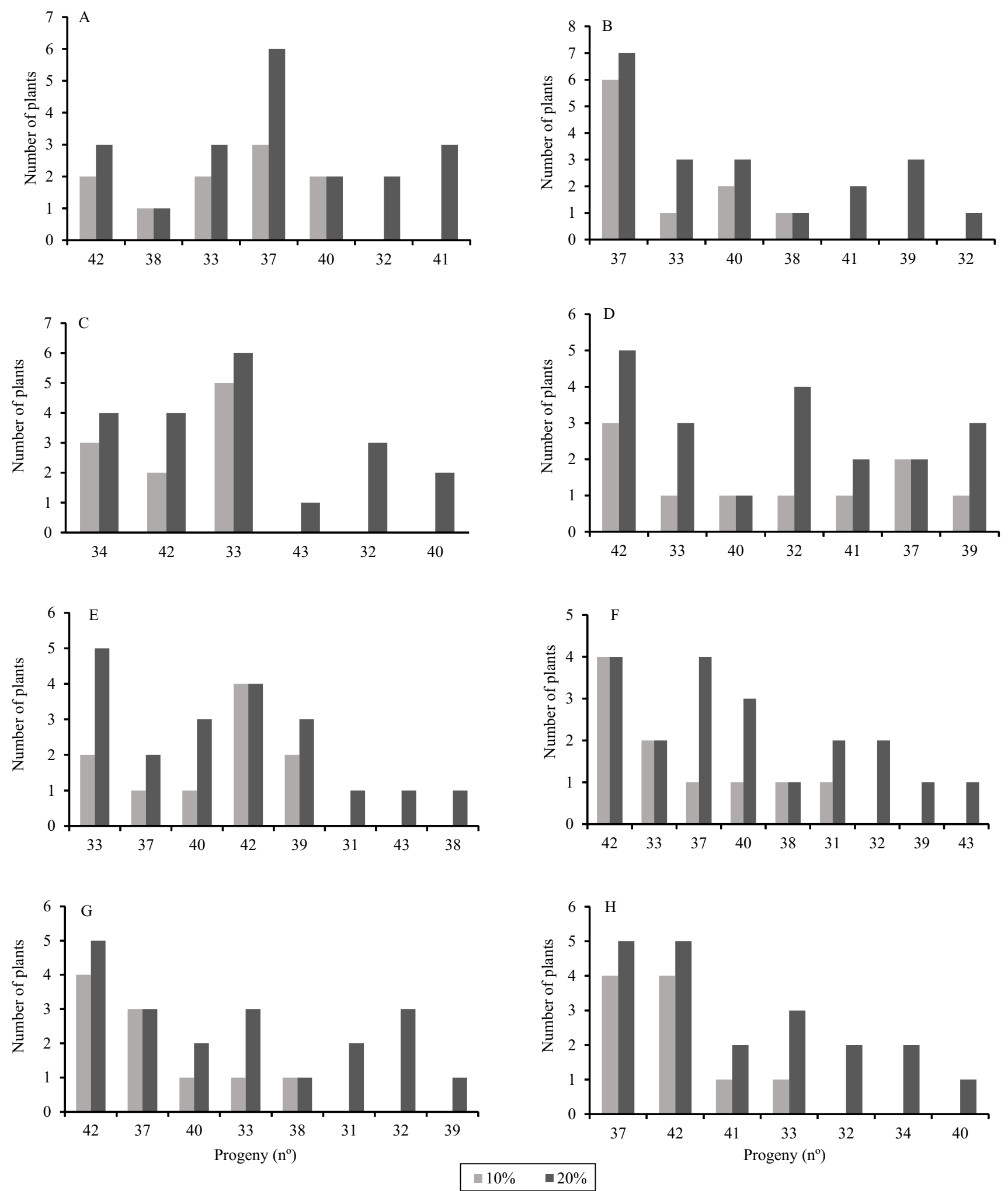

Figure 2. Number of plants from the best full-sib progenies of assai palm (Euterpe oleracea) for the juvenile traits: A, number of leaves (NL); B, number of emerged leaves (NEL); C, number of dead leaves (NDL); D, total leaf length (TLL); E, leaf sheath length (LSL); F, girth circumference (GC); G, plant height (PH); and H, number of leaflet pairs (NLP), in five measurements. 
traits TLL, LSL and NLP, while 37 stood out for NEL and NL. However, these progenies need to be better evaluated for other traits, particularly those related to fruit production and pulp quality.

The ideal cultivar of the assai palm tree should be selected not only for one trait, but for several traits of interest simultaneously. One way to conduct this selection is by applying the method of independent elimination levels, which allows assigning desired thresholds to each trait, in order to select only the individuals that meet the requirements established by the breeder. Therefore, considering the traits NL, TLL, LSL and GC, the individuals selected were 329, 257, 334, 291, 332, 302, 260, 294, 295, and 316 (Figure 5), which showed superior performance for almost all traits and were derived from the best progenies. The individuals 329, 334, and 332 were from progeny 42, the individuals 291, 294, and 295 from progeny 37, the individuals 257 and 260 from progeny 33, and the individuals 302 and 316 from progenies 38 and 40, respectively.

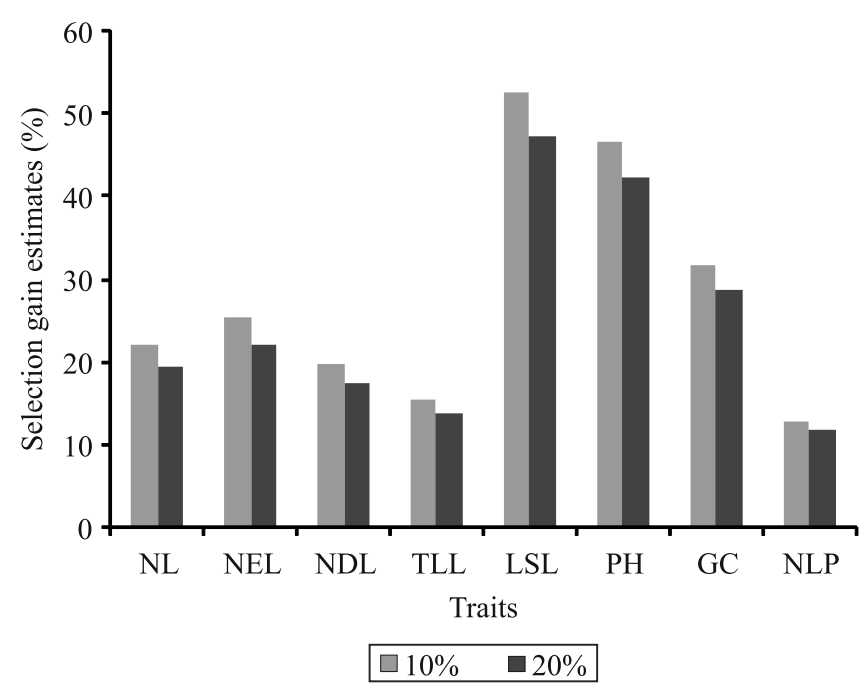

Figure 3. Selection gain estimates of the best individuals of full-sib progenies of assai palm (Euterpe oleracea) evaluated in five measurements, assuming 10 and $20 \%$ selection intensities, for the traits: NL, number of leaves; NEL, number of emerged leaves; NDL, number of dead leaves; TLL, total leaf length; LSL, leaf sheath length; PH, plant height; GC, girth circumference; and NLP, number of leaflet pairs.
Among juvenile traits, those related to fruit production should be emphasized. The traits NL, TLL, LSL and GC, considered important, were also used in simultaneous selection in other studies (Oliveira et al., 2000; Galate et al., 2012). In the present work, simultaneous selection allowed identifying promising assai palm plants with favorable performance for almost all the juvenile traits measured, which might lead to trees with productive potential. Farias Neto et al. (2012) assessed open-pollinated progenies of assai palm at the juvenile stage and used the traits plant height, diameter at breast height, number of green leaves, and number of tillers for selective purposes. These authors concluded that the best individuals had a positive correlation with plant height and diameter at breast height, which may allow favorable changes in fruit production and the possibility of early selection. Therefore, selection for juvenile traits might be useful to provide genetic gain for fruit production.

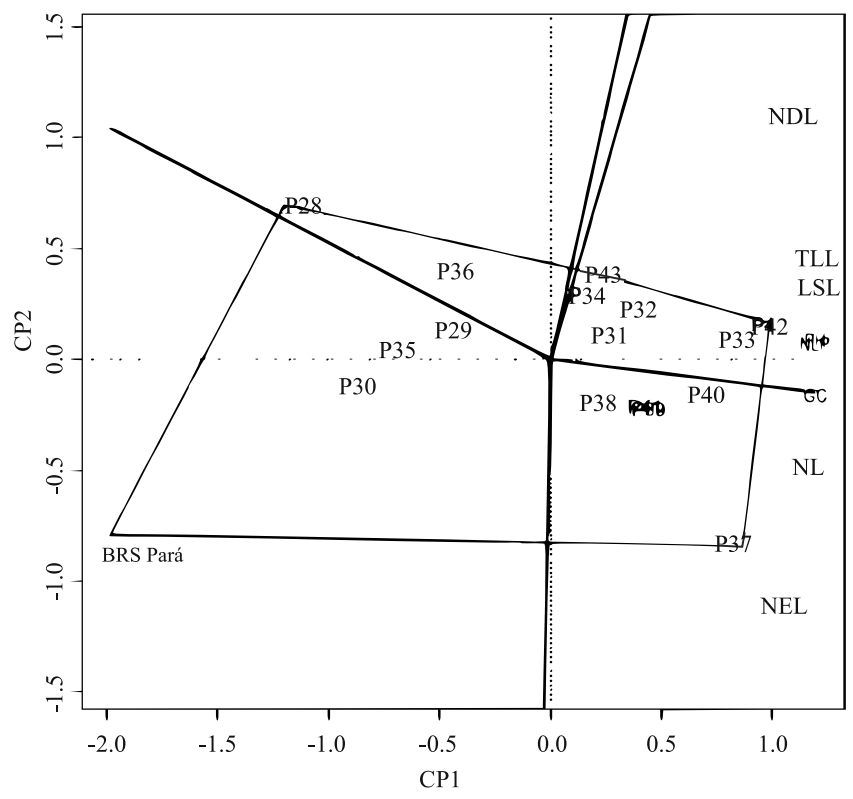

Figure 4. Polygon with scores of full-sib progenies of assai palm (Euterpe oleracea) and of the traits: NDL, number of dead leaves; TLL, total leaf length; LSL, leaf sheath length; $\mathrm{PH}$, plant height; NLP, number of leaflet pairs; GC, girth circumference; NL, number of leaves; and NEL, number of emerged leaves.

Pesq. agropec. bras., Brasília, v.53, n.7, p.815-823, July 2018 DOI: 10.1590/S0100-204X2018000700005 

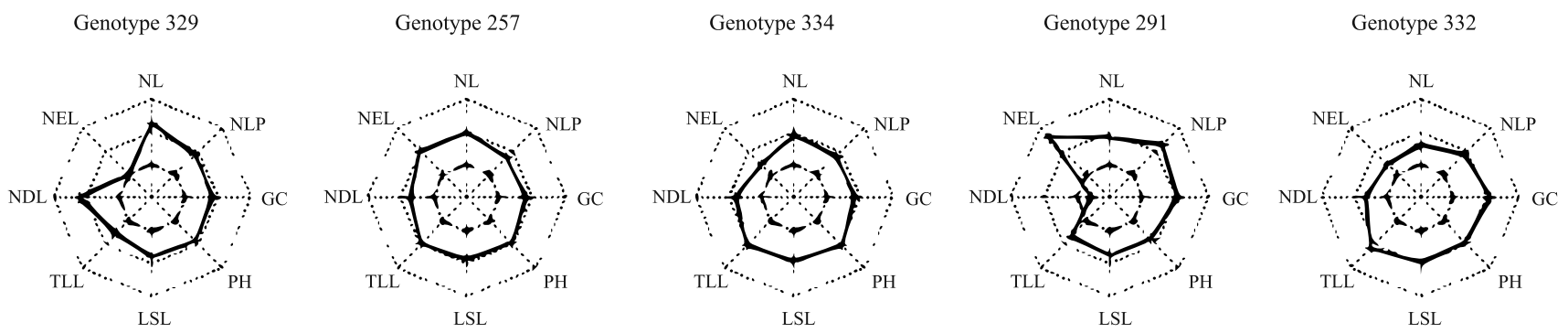

Genotype 302

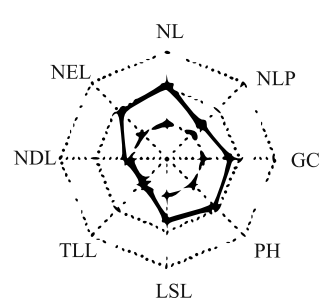

Genotype 260

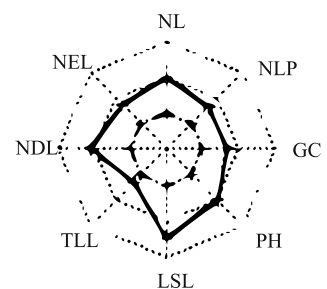

Genotype 294

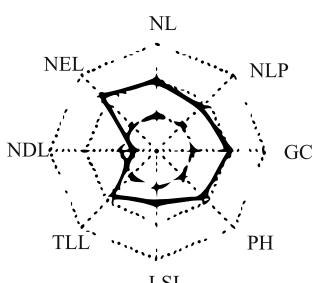

Genotype 295

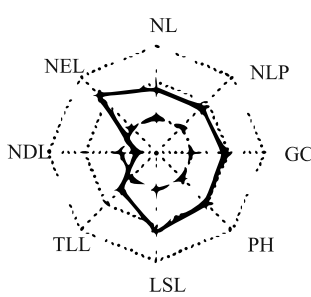

Genotype 316

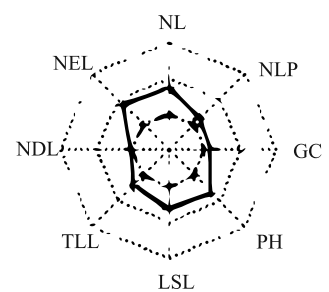

Figure 5. Graphical representation of genetic values for juvenile traits of the ten best individuals of full-sib progenies of assai palm (Euterpe oleracea) evaluated in five measurements, based on the method of independent elimination levels, considering the traits number of leaves, leaf sheath length, and girth circumference. NL, number of leaves; NLP, number of leaflet pairs; GC, girth circumference; PH, plant height; LSL, leaf sheath length; TLL, total leaf length; NDL, number of dead leaves; and NEL, number of emerged leaves.

\section{Conclusions}

1. The mean heritabilities of the full-sib progenies of assai palm (Euterpe oleracea) allow to obtain genetic gain, mainly for the juvenile traits leaf sheath length, number of leaves, and plant height.

2. The full-sib progenies P33, P37, and P42 present superior genetic values for several juvenile traits and might be considered promising for fruit production.

\section{Acknowledgments}

To Embrapa Amazônia Oriental, to the graduate plant breeding and genetics program of Universidade Federal de Lavras (Ufla), and to Coordenação de Aperfeiçoamento de Pessoal de Nível Superior (Capes), for scholarship granted and financial support.

\section{References}

FARIAS NETO, J.T. de; OLIVEIRA, M. do S.P. de; MULLER, A.A.; NOGUEIRA, O.L.; ANAISSI, D.F. dos S.P. Variabilidade genética em progênies jovens de açaizeiro. Cerne, v.11, p.336-341, 2005.

FARIAS NETO, J.T. de; OLIVEIRA, M. do S.P. de; RESENDE, M.D.V. de; RODRIGUES, J.C. Parâmetros genéticos e ganhos com a seleção de progênies de Euterpe oleracea na fase juvenil. Cerne, v.18, p.515-521, 2012. DOI: 10.1590/S0104-77602012000300020.

FRUTOS, E.; PURIFICACIÓN GALINDO, M.; LEIVA, V. An interactive biplot implementation in R for modeling genotype-byenvironment interaction. Stochastic Environmental Research and Risk Assessment, v.28, p.1629-1641, 2014. DOI: 10.1007/ s00477-013-0821-Z.

GALATE, R. dos. S.; MOTA, M.G. da C.; GAIA, J.M.D.; COSTA, M. do S.S. Caracterização morfoagronômica de germoplasma de açaizeiro no nordeste paraense. Revista Brasileira de Fruticultura, v.34, p.540-550, 2012. DOI: 10.1590/S010029452012000200028.

MRODE, R.A. Linear models for the prediction of animal breeding of animal breeding values. $2^{\text {nd }} \mathrm{ed}$. Cambridge: CABI, 2005. 344p. With chapter 15 contributed by Robin Thompson. DOI: $10.1079 / 9780851990002.0000$.

NUNES, J.A.R.; RAMALHO, M.A.P.; ABREU, A. de F.B. Graphical method in studies of adaptability and stability of cultivars. Annual Report of the Bean Improvement Cooperative, v.48, p.182-183, 2005. 
OLIVEIRA, M. do S.P. de; FARIAS NETO, J.T. de. Cultivar BRS-Pará: açaizeiro para produção de frutos em terra firme. Belém: Embrapa Amazônia Oriental, 2004. 3p. (Embrapa Amazônia Oriental. Comunicado técnico, 114).

OLIVEIRA, M. do S.P. de; FERREIRA, D.F.; SANTOS, J.B. dos. Divergência genética entre acessos de açaizeiro fundamentada em descritores morfoagronômicos. Pesquisa Agropecuária Brasileira, v.42. p.501-506. 2007. DOI: 10.1590/S0100204X2007000400007.

OLIVEIRA, M. do S.P. de; LEMOS, M.A.; SANTOS, V.F. dos; SANTOS, E.O. dos. Correlações fenotípicas entre caracteres vegetativos e de produção de frutos em açaizeiro. Revista Brasileira de Fruticultura, v.22, p.1-5, 2000.

OLIVEIRA, M. do S.P. de; MOCHIUTTI, S.; FARIAS NETO, J.T. de. Domesticação e melhoramento do açaizeiro. In: BORÉM, A.; LOPES, M.T.G.; CLEMENT, C.R. (Ed.). Domesticação e melhoramento: espécies amazônicas. Viçosa: Universidade Federal de Viçosa, 2009. p.207-235.

PIEPHO, H.-P.; ECKL, T. Analysis of series of variety trials with perennial crops. Grass and Forage Science, v.69, p.431-440, 2013. DOI: $10.1111 /$ gfs.12054.

RESENDE, M.D.V. de. SELEGEN-REML/BLUP: sistema estatístico e seleção computadorizada via modelos lineares mistos. Colombo: Embrapa Florestas, 2007. 359p.

RESENDE, M.D.V. de. Software Selegen-REML/BLUP: a useful tool for plant breeding. Crop Breeding and Applied Biotechnology, v.16, p.330-339, 2016. DOI: 10.1590/1984-70332016v16n4a49.

RESENDE, M.D.V. de; DUARTE, J.B. Precisão e controle de qualidade em experimentos de avaliação de cultivares. Pesquisa Agropecuária Tropical, v.37, p.182-194, 2007.
RESENDE, M.D.V.; DIAS, L.A.S. Aplicação da metodologia de modelos mistos (REML/BLUP) na estimação de parâmetros genéticos e predição de valores genéticos aditivos e genotípicos em espécies frutíferas. Revista Brasileira de Fruticultura, v.22, p.44-52, 2000.

RUFINO, M. do S.M.; PÉREZ-JIMÉNEZ, J.; ARRANZ, S.; ALVES, R.E.; BRITO, E.S. de; OLIVEIRA, M.S.P.; SAURACALIXTO, F. Açaí (Euterpe oleraceae) 'BRS Pará': a tropical fruit source of antioxidant dietary fiber and high antioxidant capacity oil. Food Research International, v.44, p.2100-2106, 2011.

SANTOS, H.G. dos; JACOMINE, P.K.T.; ANJOS, L.H.C. dos; OLIVEIRA, V.A. de; LUMBRERAS, J.F.; COELHO, M.R.; ALMEIDA, J.A. de; CUNHA, T.J.F.; OLIVEIRA, J.B. de. Sistema brasileiro de classificação de solos. 3.ed. rev. e ampl. Brasília: Embrapa, 2013. 353p.

YAMAGUCHI, K.K. de L.; PEREIRA, L.F.R.; LAMARÃO, C.V.; LIMA, E.S.; VEIGA-JUNIOR, V.F. da. Amazon acai: chemistry and biological activities: a review. Food Chemistry, v.179, p.137$151,2015$.

YAN, W.; RAJCAN, I. Biplot analysis of test sites and trait relations of soybean in Ontario. Crop Science, v.42, p.11-20, 2002. DOI: $10.2135 /$ cropsci2002.1100.

YOKOMIZO, G.K.I.; FARIAS NETO, J.T de; OLIVEIRA, M. do. S.P. de. Ganho esperado na seleção de progênies de polinização aberta de Euterpe oleracea para produção de frutos. Scientia Florestalis, v.44, p.241-248, 2016. DOI: 10.18671/scifor. v44n109.23.

YOKOMIZO, G.K.-I.; QUEIROZ, J.A.L. de; MOCHIUTTI, S.; PINHEIRO, I. de N.; SILVA, P.A.R. da. Desempenho de progênies de açaizeiros avaliadas para caracteres agronômicos no Estado do Amapá. Scientia Florestalis, v.38, p.367-376, 2010.

Received on June 26, 2017 and accepted on October 10, 2017

Pesq. agropec. bras., Brasília, v.53, n.7, p.815-823, July 2018 DOI: $10.1590 / \mathrm{S} 0100-204 X 2018000700005$ 